\title{
O olhar de Medusa e a reparação do mundo: 6 flashes e um álbum aberto
}

\author{
Ana Paula Coutinho \\ Universidade do Porto - ILC
}

\begin{abstract}
Resumo: Pensar sobre a "salvação do mundo" a partir da fotografia, entendida como arte do olhar, e não apenas como resultado de um mecanismo ótico ou como fenómeno social de comunicação, conduz-me a um conjunto de breves reflexões que visam equacionar, por um lado, a ideia de "salvação" como um paradigma de "reparação" na literatura contemporânea, e, por outro, algumas condições intrínsecas e extrínsecas para que a imagem fotográfica, num processo mais ou menos longo que vai da captura pela câmara do olhar do/a fotógrafo/a até à sua recepção pelo(s) olhare(s) de diferentes espectadores, participe efetivamente de uma revelação desacelerada e mundificante da realidade, tanto para uns como para outros.
\end{abstract}

Palavras-chave: fotografia, reparação, projeto fotográfico, kalokagathia

\begin{abstract}
In Thinking about the "salvation of the world" from the vantage point of photography, understood not so much as the product of an optical mechanism or as a form of social communication but as the art of the gaze, has led me to gather a series of reflections which seek to elucidate, on the one hand, the idea of "salvation" as a "reparation" paradigm in contemporary literature and, on the other, some intrinsic and extrinsic conditions, through a more or less protracted process that extends from the rendering of the photographer's gaze by the camera to its reception by the gaze(s) of different spectators, that allow the photographic image to effectively participate in a leisurely and life-enhancing revelation of reality that all kinds of viewers can enjoy.
\end{abstract}

Keywords: photography, reparation, photography project, kalokagathia 
Depois de tanto se insistir na ideia de "fim" (fim de século, fim de ciclo, fim do livro, fim da História, fim das ideologias, fim do mundo...), de tanto recorrer à razão apocalíptica, quase sempre entregue a uma paralisia conservadora malgré elle, como mostra Michaël Foessel em Après la Fin du Monde. Critique de la raison apocalyptique (2012), torna-se muito estimulante desprendermo-nos desse comprazimento declinista e arriscar um (re)início que, sem esquecer os sinais de crise, vai ao encontro do sentido etimológico de "apocalipse" como revelação, de acordo com uma leitura existencial do livro bíblico homónimo, cuja “arquitetura em movimento” extravasa da mera sequência temporal.

Pedro Eiras, o grande mentor desta continuada reflexão escatológica, designou a retoma como “Seminários da Salvação do Mundo", optando por, de novo, fazer um voo rasante sobre uma isotopia de cunho religioso, embora logo dela se desvie, quanto mais não seja pelas imagens escolhidas para os excelentes cartazes de divulgação desta primeira série. A força, não apenas indicial mas também icónica, que ressalta dessas imagens, desvia-se de qualquer salvação etérea para se acolher no domínio que chamarei, antes, da “reparação”. Um canivete suíço, um martelo, uma chave de boca e aperto ou um alicate servem para reparar e não para salvar, no sentido de curar, de dar saúde, ou mesmo de libertar o espírito. Se a conjunção do título dos seminários e das imagens de ferramentas podem apontar para uma ironia desconstrucionista, eu opto antes por ver nessa associação um repto construtivo, que aproveito para direccionar para a fotografia, por amável sugestão do Pedro Eiras que conhece o meu já longo e paralelo interesse por esse domínio das artes visuais.

Aquilo que a seguir exponho, em seis designados flashes e num pequeno álbum aberto, dá forma à reflexão que fui levada a fazer, quando me lancei a mim mesma a pergunta se, e até que ponto, a fotografia pode ser salvífica ou, numa palavra porventura menos ambiciosa, reparadora.

\section{IO Flash - Proclamação do fim e recomeço.}

Em 2017, um dos Directores de investigação do CNRS em França, Alexandre Gefen, propôs-se explorar linhas de força do panorama literário francês do início deste século, e fê-lo a partir daquilo que, segundo ele, configura um paradigma clínico de “reparação do mundo”. Essa tendência assenta numa transformação da própria ideia de literatura, segundo a qual os actos de escrita e de leitura literária procuram reparar as comunidades contemporâneas, religando e colmatando as suas falhas e fissuras (Gefen 2017: II), quando parece estarem já esgotadas outras instâncias e formas de mediação do foro social, político ou religioso. A ideia de “reparação do mundo" poderá assim confundir-se com uma finalidade terapêutica da literatura, a qual, por contraposição à autonomia kantiana da "finalidade sem fim" da arte, vai ao encontro de problemáticas candentes na sociedade actual, como sejam: a busca da visibilidade, a procura 
da singularidade e da afirmação do indívíduo; a reacção aos traumas e à doença; as formas de cuidar do(s) outro(s), de proteger o mundo, ou de pensar o global; o apelo a uma justiça retrospectiva, ou o resgate do esquecimento, isto para referir apenas aqui algumas das vertentes desse paradigma restaurador analisado por Alexandre Gefen.

Embora o ensaísta remeta para um determinado corpus literário nacional, a sua perspectiva crítica parece-me igualmente operativa para outros contextos, tanto literários como de outras artes, e, neste caso, vai precisamente ao encontro dos utensílios de reparação que ressaltam da assinatura visual e provocatória destes seminários.

A aceleração exponencial de mudanças a que se tem assistido nos últimos 20-30 anos, coincidindo com uma viragem de século e de milénio, provocou uma sensibilidade crescente para os sinais iminentes de catástrofe, por risco de um desastre ecológico à escala planetária, ou de uma crise humanitária global, em grande medida provocada pela falência de um modelo de sociedade assente nos tentáculos de um capitalismo selvagem, promovido e disseminado pelos simulacros da rede comunicacional que a gerem.

Depois da "sociedade do espectáculo" (Debord 1967) e da "sociedade do consumo" (Baudrillard 1970), que o século passado exponenciou, confrontamo-nos cada vez mais com os efeitos da chamada "sociedade do cansaço", como lhe chama Byung-Chul Han (2015), que, na senda da dialéctica negativa da Escola de Frankfurt, atribui esse quadro de exaustão a um excesso de positividade, em virtude da qual, por coerção directa ou indirecta, tendemos a viver obcecados por índices de desempenho e de produção, incapazes de reagir contra aquilo que nos debilita e que, de algum modo, nos torna cúmplices de um mundo à deriva, ou em constante fuga para a frente, em direcção ao desconhecido.

Face a este quadro, a chamada "inflexão ética” da/na literatura a que se assiste desde os anos 90, com reflexos tanto na criação como na crítica, propõe-se: ı) ultrapassar os pensadores da suspeita, desde Nietzsche aos pós-estruturalistas, no que respeita à capacidade de a linguagem representar o real; 2) questionar uma dada leitura da teologia negativa que sustenta o absoluto da autonomia estética e 3) contornar de algum modo o relativismo epistemológico associado ao ecletismo pósmodernista. Promover uma atenção ao ethos da obra de arte, ou seja, ao sentido que dela emerge no que respeita ao sentido da existência e da relação do sujeito com tudo aquilo que o rodeia - chamemos-lhe mundo - surge na linha de um manifesto reinvestimento nas relações entre arte e política, de acordo com aquele que é o propósito comum de "organização do sensível”, para aqui utilizar a expressão de Jacques Rancière (2000).

Encaro, pois, aqui a "salvação" como um horizonte de desejo, como apetência ou disponibilidade para "reparar o mundo"; por outras palavras, como inscrição num movimento de resistência ao sentido terminal de fim: "O mundo não conhece o repouso do movimento do mundo”, ouve-se e vê-se no filme de Yoann Bourgeois e Louisse 
Narbori, a partir de uma extraordinária coreografia realizada em 2019, no Panthéon de Paris, com o título Les Grands Fantômes.

Julgo também que se poderá encarar este investimento simultaneamente mundano e mundificante das/nas artes, como um modo de proceder à calibração nas relações entre poiesis e experiência do mundo, questionando, por um lado, o primado da autonomia estética como absoluto e, pelo outro, exigindo um espírito crítico sempre alerta quanto ao riscos de poder confundir-se "arte implicada" com algumas receitas para a angústia existencial e social do sujeito contemporâneo (Gefen 2017: 270), ou com doutrinas e outras panaceias, de cujos resultados finais a História nos leva a suspeitar de imediato.

\section{$2^{0}$ Flash - De que fotografia (não) falo.}

De molde a procurar responder concretamente à pergunta se a fotografia concorre (de que modo) para a reparação do mundo, sou obrigada a delimitar o campo de análise do universo fotográfico, que tem conhecido um extraordinário e exponencial desenvolvimento, sobretudo ao longo das últimas décadas, isto é, à medida que se foi impondo um modelo de sociedade completamente dependente da imagem visual.

Ainda que, por definição, possamos considerar fotografia toda a imagem feita a partir de uma câmara que, através da luz filtrada por uma lente, faz reagir a emulsão fotossensível numa película, anteriormente revelada (fotografia analógica), ou que acciona um captador constituído por milhões de sensores (pixels) que, por sua vez, transformam o sinal luminoso em sinal eléctrico numa memória digital posteriormente transformada em imagem num computador (fotografia digital), parece-me improcedente considerar para efeito desta reflexão aquele tipo de fotografia que corresponde apenas a uma prática de registo pessoal ou familiar, exponenciada por gestos compulsivos e próprios da cultura de massas. É essa fotografia que tende a ser recebida ingenuamente, como se o mundo exterior e a fotografia fossem a mesma coisa, ou como se estivessem sujeitos ao mesmo tipo de apreensão.

É certo que poderia resolver a questão dos limites do corpus, dizendo que me reporto aqui à fotografia enquanto arte (o que não coincide forçosamente com "arte ou técnica fotográficas”), mas isso arrastaria consigo outros problemas, uma vez que estaria a cingir-me a uma triagem ditada pelas regras da arte, tal como Pierre Bourdieu desenvolveu na sua conhecida obra de 1992, ou seja, bastantes anos depois de, com outros, se ter dedicado a analisar as regras e funções sociais da fotografia, atribuindo-lhe a categoria de "uma arte média" (Bourdieu 1965), leia-se, uma arte sem aura, destinada a acabar numa "caixa de sapatos”. Se fosse hoje, seria levado a dizer num telemóvel ou numa nuvem informática...

Assim, independentemente da existência ou não do selo de certificação artística, falo aqui de imagens fotográficas realizadas através de uma câmara, por profissionais 
e amadores, imagens essas que, embora estejam sujeitas a um apparatus, no sentido que Vilém Flusser atribui a este termo,' não são apenas resultado de produção digital. São fotografias que implicam a conjugação da técnica, do saber e da sensibilidade de quem maneja a câmara, e que conservam uma significação irredutível ao momento e à intencionalidade que lhes deram origem. Por outras palavras, refiro-me àquelas fotografias de que Susan Sontag diria que "transformam e ampliam as nossas noções do que vale a pena olhar e do que pode ser observado" (2012: II), onde se vislumbra um desejo de "clarificação do mundo pela sua imagem", recorrendo àquela que considero uma muito feliz expressão do psiquiatra e psicanalista Serge Tisseron (1996), autor que se tem dedicado a estudar as relações entre imagem (designadamente a fotografia) e inconsciente.

\section{$3^{0}$ Flash - 0 projecto fotográfico.}

Dentre os géneros de fotografia em que se pode reconhecer existir um potencial de reparação do mundo, no sentido atrás apontado, encontra-se a chamada "fotografia documental", que é uma categoria de contornos bastante fluídos: tanto remete para o fotojornalismo ou para a tradição das chamadas "fotografia social" e "fotografia humanista", que resultam do desenvolvimento das ciências sociais e da expansão da imprensa ilustrada no século XX, como pode designar a fotografia de apoio à investigação científica, ou ainda remeter para outros domínios híbridos de pesquisa e arte, de informação e ensaio, na fronteira entre documento, ficção ou poesia.

Um dos principais elementos comuns a essa panóplia de contextos envolvendo o acto fotográfico é justamente o facto de as imagens daí resultantes não se limitarem ao momento da sua captura. Quer isto dizer que a fotografia documental, tal como o espectador a pode depois ver, além de estar sujeita às características de programação da câmara e de outros acessórios fotográficos, depende de decisões e regras prévias, assim de formas de edição e de difusão posteriores, que por vezes excedem o domínio de actuação do próprio fotógrafo.

O potencial narrativo da fotografia fez com que, na primeira metade do século $X X$, se começasse a promover um certo fotojornalismo como propulsor da imprensa, como foi o caso da revista americana Life, onde W. Eugène Smith, considerado um dos pioneiros do ensaio fotográfico, começou a desenvolver os seus trabalhos de fotografia humanista directamente ligada a problemáticas sociais.

As fotografias obtidas em missões de trabalho de jornalistas e repórteres, de fotógrafos profissionais ou amadores, de viajantes ou de cientistas, ${ }^{2}$ passaram assim a fazer parte de um património visual colectivo, contribuindo de forma indelével para uma certa ideia ou conhecimento do mundo, da sua diversidade e mudanças, dos acontecimentos e personagens considerados como mais marcantes. Algumas dessas fotografias viriam assim a ganhar um valor icónico, mais até do que informativo, na 
medida em que funcionam como síntese visual de um dado acontecimento que viria a mudar o curso da História. Assim aconteceu com fotografias como a da pequena vietnamita a fugir das chamas de Napalm durante a Guerra no Vietname; a do astronauta Neil Armstrong a pisar pela primeira vez a Lua; a de Salgueiro Maia, destacado e pensativo, no Largo do Carmo, no dia 25 de Abril de 1974; a do indivíduo completamente só diante dos tanques de guerra, aquando do massacre de jovens na Praça de Tianamen, em 1989; ou mais recentemente, a do corpo morto do pequeno refugiado sírio, Aylan Kurdi, numa praia da Turquia.

A partir do momento em que uma das principais virtualidades da fotografia é dar a ver fragmentos da realidade do seu tempo; testemunhar momentos de celebração, de crise ou de catástrofe, essa sua vertente indicial funciona como reparação da falha ontológica existente entre um momento passado e o presente, mesmo quando essa sutura assenta em imagens que, em si mesmas, deixam ver mais sinais de destruição do que de (re)construção.

Mas para que essas fotografias possam ser reparadoras da ausência, de algum modo presentifiquem e denunciem aquilo que o espectador não viveu ou já não vive, é necessário existir alguma informação adicional, sob pena de a vertente documental dessas imagens passar despercebida, ou poder vir a ser de alguma forma adulterada. ${ }^{3}$ Além disso, importa ter presente que qualquer fotografia documental integra uma cadeia comunicacional que supõe, a montante, uma decisão de procurar saber e de querer testemunhar, enquanto, a jusante, implica uma vontade de ver e de conhecer, quando não mesmo de intervir no mundo.

Com o aproximar do final do século XX, um pouco por todo o lado, foram publicadas crónicas e Histórias do Século baseadas em fotografias, prolongando desse modo não apenas a tradição já oitocentista das Histórias ilustradas, como ainda o hábito promocional de números temáticos e edições comemorativas dos periódicos. Esse tipo de publicações, em geral muito apelativas, destina-se a cativar o público em geral, ou sobretudo coleccionadores, quando se trata de edições de luxo, de tiragem limitada. No entanto, poucas vezes esses álbuns esclarecem efectivamente aquilo para que remetem, já para não dizer que ignoram, ou permitem ignorar, o potencial crítico da legibilidade das imagens, que Aby Warburg, ainda no início desse mesmo século XX, procurava imprimir ao seu inacabado Atlas imagético, recorrendo a painéis de fotografias que testemunhavam a permanência de determinados valores expressivos ao longo da História.

Essa componente (auto)crítica da imagem fotográfica seria também assinalada, pouco depois, por Walter Benjamin na sua "Pequena História da Fotografia” (193I), ao escrever: "O analfabeto do futuro [será], não o incapaz de escrever, mas o incapaz de fotografar” (1992: 135), para de seguida considerar também “pouco mais do que analfabeto o fotógrafo que não sabe ler as suas fotografias” (ibidem), chamando assim a atenção para a importância da legendagem ou de um prolongamento textual da 
própria fotografia, que, em vez que acentuar a ilusão mimética ou a tautologia, a integre num projeto mais abrangente de emancipação crítica do sujeito, seja do próprio fotógrafo, seja do espectador das imagens.

No domínio dos ensaios e projetos fotográficos que vieram a fazer História, caberia aqui lembrar, entre tantos outros, os trabalhos de fotógrafos como Robert Capa, Josef Koudelka, Walker Evans, Robert Frank, Andre Kertesz, Cartier-Bresson ou Dorothea Lange. Regresso, no entanto, a Sebastião Salgado , para ilustrar a vertente ética da noção mais ampla de projecto fotográfico, para que têm contribuído decisivamente o trabalho e a visibilidade deste fotógrafo brasileiro.

Nos finais da década de 80, Sebastião Salgado começou a dedicar-se a um trabaIho mais autónomo e sistemático de reflexão visual sobre o "estado do mundo", mais liberto, pois, do ritmo e dos propósitos do fotojornalismo, reflexão essa que viria a traduzir-se em sucessivos álbuns, como Outras Américas (1986), sobre o êxodo rural, e passando por outros; Trabalhadores (1992), dedicado ao mundo do trabalho na era industrial; Terra (1997), consagrado ao Brasil e ao Movimento dos Sem Terra, ou $\hat{\varepsilon} x o d o s$ (2000), publicado no limiar deste século, inteiramente dedicado à "era das migrações e dos refugiados”. Este último trabalho, que inclui uma breve contextualização da problemática, além de um anexo com uma breve legendagem para cada uma das imagens, desdobrou-se em diferentes iniciativas e plataformas, para lá da edição do álbum: exposições, publicações pontuais na imprensa, palestras e demais programas educativos específicos. Não têm faltado, entretanto, críticas ao tipo de projecto fotográfico de Sebastião Salgado, em geral assentes na sua alegada deriva mercantilista, e naquilo que é julgado como uma "esteticização do sofrimento", fotografia colada a um discurso de "boas intenções”, em suma, uma "retórica beata do género «A Família do Homem »", numa alusão a The Family of Man, uma enorme exposição de fotografia que teve lugar em 1955, no MoMa de Nova Iorque.

Um ensaísta como Georges Didi-Huberman resumiria dizendo que àquela exposição, como em geral aos trabalhos de Sebastião Salgado, falta a consciência dialéctica de um gaio saber inquieto. 0 autor de Quando as Imagens Tomam Posição sugere aliás que Bertolt Brecht terá pretendido responder à irrelevância optimista da exposição The Family of Man com a sua Kriegsfibel, uma colagem de fotografias retiradas dos jornais e comentadas com alguns dos seus próprios poemas, onde, ao contrário da visão conservadora de The Family of Man, não faltam o agenciamento lúdico, o humor e os desvios dialécticos (Didi-Huberman 2009: 195).

Já para Susan Sontag, autora de Olhando o Sofrimento dos Outros, não só a compaixão provocada por uma certa estética humanitária tende a provocar no espectador um misto de sentimentos de inocência e de impotência (2015: 99), como o maior óbice das fotografias de Sebastião Salgado reside no anonimato a que votam os mesmos indivíduos que, justamente, pretendem resgatar do esquecimento ou da injustiça social: 
Um retrato que recusa nomear o seu sujeito torna-se cúmplice, ainda que inadvertidamente, do culto da celebridade que alimentou um apetite insaciável pela sorte oposta da fotografia: reservar um nome apenas aos famosos reduz o resto a instâncias representativas das respetivas ocupações, etnias, condições. (idem: 79)

Não me alongarei aqui sobre o modo como o próprio Sebastião Salgado e alguns outros críticos de fotografia têm rebatido essas reservas, mas gostaria de realçar aquilo que mais pesou para trazer à colação o seu projecto fotográfico, neste contexto de reflexão sobre as relações possíveis entre fotografia e salvação: a sua recente aposta numa perspetiva do mundo nitidamente mais esperançosa que, em 2020, deu origem à exposição e ao álbum intitulados Génesis.

Depois da negatividade e do pessimismo em relação à espécie humana, acumulados ao longo dos anos em que o fotógrafo trabalhou sobre diversas formas de injustiça e violência, e que alegadamente lhe tinham retirado qualquer confiança numa "salvação" da humanidade, Sebastião Salgado sentiu necessidade de se dedicar a um projecto fotográfico completamente distinto, que duraria cerca de oito anos a realizar, levando-o aos mais recônditos lugares para capturar imagens da natureza intocada ainda (ou pouco) pela civilização moderna. Pela mesma altura, fundou com Lélia Deluiz Wanik, sua mulher, o chamado Instituto Terra, na sua região natal, Aimorés, no Estado de Minas Gerais, com o objectivo de levar a cabo um vasto trabalho de restauração ecossistémica através da recuperação da mata atlântica da região, e também de promover projetos educativos e de investigação científica, com base nas fotografias de Génesis que visam sensibilizar para, e promover a ecologia e a acção solidária.

A nível da intencionalidade autoral, como da sua extensão pragmática, todo o projecto Génesis configura um gesto reparador do mundo, por muito que possa continuar sujeito à inexorável lógica capitalista que pretende denunciar. Estamos de facto perante fotografias arrebatadoras que comprovam à exaustão que aquilo a que chamamos mundo contemporâneo é composto de uma diversidade extraordinária de realidades, seres e vivências... No entanto, e no que tocaao discurso estético das fotografias, têm-se erguido de novo várias reservas àquele que é considerado, por alguns, um discurso ontoepistemológico de raiz colonial, por se construir "sobre" e não com “o Outro”, e por assentar em binarismos como natureza/cultura, primitivo/ contemporâneo ou humanos/animais, que em si mesmos cristalizam uma ideia de existências a-históricas.

Será, contudo, forçado pretender inferir daí que um álbum como Génesis mais não faz do que expor um direito imperial de objectivar o mundo das pessoas, sem que a sua existência verdadeiramente nos afecte (Feldhues / Silva Júnior 2020), pois, ao mesmo tempo, isso significa ignorar, por exemplo, os programas educativos a que esse álbum ele tem sido associado, procurando que o confronto com o impacto das imagens mude mentalidades e comportamentos relativamente à imensa diversidade 
da Terra como "Ca(u)sa comum”. Do mesmo modo, parece abusivo considerar que a palavra "Génesis" tutela uma espécie de programa de exaltação do passado, por oposição ao mundo moderno, pois o quadro de enunciação em que se insere este projectootográfico é muito claro quando vinca o propósito de expor sinais de vida na Terra onde se apoiam tanto a responsabilidade como a esperança pelo futuro do planeta. Mas, se é verdade que alguns dos referidos julgamentos não são, em rigor, aplicáveis àquele trabalho de Sebastião Salgado, convém sublinhar que não deixa de ser importante atentar nas contradições geradas por projectos fotográficos que, parecendo à partida guiar-se por um propósito de reparação do mundo, acabam por exercer uma violência sobre ele, por não integrarem ou desencadearem nenhuma forma de o transformar, a começar logo pelo estímulo do espírito crítico do espectador.

\section{Flash - Para mais tarde recordar.}

A publicidade da Kodak, empresa americana de material fotográfico, fundada ainda no século XIX (1888) e que haveria de dominar o século XX ao ponto de funcionar como antonomásia de "fotografia” no léxico da cultura popular, acertou em cheio quando criou o slogan "para mais tarde recordar”, porque criou uma mnemónica para a virtualidade salvífica de um simples disparo da câmara fotográfica.

Claro que nunca veremos um slogan a lembrar que uma fotografia opera um corte memorável porque elimina aquilo que, ficando fora de campo de visão, é votado ao esquecimento. A esse nível, bastam alguns casos históricos de censura para perceber que uma fotografia regista aquilo que lhe é permitido registar. No entanto, sem mesmo qualquer manipulação posterior ao acto fotográfico, somos levados a convir que a fotografia funciona como uma excelente metáfora da construção da memória que, contudo, não existe sem o reverso do esquecimento. Tanto para a fotografia como para a memória, o acto principal é escolher e eliminar (John Zsarovski), decisão essa que compreende sempre um valor ético em si e por si (Sontag 2015: 112).

Ora, grande parte do pensamento contemporâneo sobre a fotografia acabaria por ficar indelevelmente marcado pelo ensaio de Roland Barthes, A Câmara Clara, publicado em 1980, que a prendia ao referente e ao passado "pela mesma imobilidade amorosa ou fúnebre" (Barthes 2013: 13). "O nome do noema da Fotografia será então «Isto-foi»ou, ainda, o Inacessível” - escrevia aquele semiólogo, para depois concluir que para a Fotografia existem dois caminhos dependentes da escolha do espectador: ou a submissão aos códigos da ilusão, ou o confronto com a consciência da inacessível realidade (ibidem: 130). Por sua vez, Susan Sontag viria também a insistir na dimensão elegíaca da fotografia, vendo nela "uma arte crepuscular, no âmbito da qual as fotos são memento mori, ou seja, lembretes da nossa inexorável mortalidade e, em geral, da finitude de tudo. Com efeito, logo na sua primeira obra dedicada à fotografia, a ensaísta americana afirmava que "Tirar uma foto é participar da mortalidade, da vulnerabilidade 
e da mutabilidade de outra pessoa (ou coisa)" (Sontag 20I2: 25-26). O carácter absoluto desta concepção baseada apenas numa perspectiva agónica ignora ou pelo menos subestima a extensão da própria imagem fotográfica, para lá do instante da captura e do referente visado, e por sua vez desencadeia, ou pode desencadear, uma visão daquilo que foi e já não é, mas continua a fazer parte das possibilidades do real, passado e presente.

Como bem mostrou Svetlana Boym em The Future of Nostalgia (2002), não existe apenas uma nostalgia melancólica, regressiva, mas também uma nostalgia que se projecta para o futuro. Se é certo que toda a fotografia funciona como uma pequena amostra de fim do mundo, podendo por isso provocar sentimentos melancólicos ou regressivos, convém, por outro lado, não esquecer que fotografar é uma acção contra o próprio tempo, na medida em que fica congelado tudo aquilo que integra o campo de visão da fotografia. Faz então de novo sentido pensar em Walter Benjamin, no seu modelo messiânico da História, e muito concretamente no valor salvífico que aquele filósofo alemão atribuía ao corte no fluxo historicista (Benjamin 1992: 158), tanto mais que é justamente desse ponto de ruptura que podem emergir outras imagens, por assim dizer futurantes, na medida em que superam o corte, a falha ontológica, com o vislumbre de um mundo ainda por chegar.

A presença da fotografia na literatura contemporânea parece-me vir ao encontro desse potencial simbólico e criativo, e não exactamente como prova referencial para evitar qualquer descrição verbal, nem como modo de autenticação. Na obra do escritor alemão W. G. Sebald, por exemplo, as fotografias funcionam como um elemento perturbador, instigante, que desestabiliza quer a sua componente indicial, quer o próprio discurso narrativo. Tanto o narrador como as personagens de Sebald, em romances como Emigrantes ou Austerlitz, debatem-se com o facto de apenas terem acesso a restos, fragmentos desconexos do passado, pelo que a própria função mnemónica das fotografias, a sua integração na memória cultural, acaba por ser problematizada pelo conjunto intermedial do dispositivo narrativo das obras. Mas é precisamente esse explorar da plurissignificação e da dialéctica das imagens que as liberta da tautologia e do jugo do passado estático ou unívoco.

\section{Flash - 0 invisível do olhado.}

A maior crítica que, no seu Salon de 1859, Baudelaire fazia à fotografia tinha a ver com o facto de esta afastar o público da verdade artística, fazendo-o acreditar que Ihe dava a ver a integralidade do real, e, por isso mesmo, impedindo-o de iniciar-se a outras possibilidades, acessíveis apenas pela imaginação, aquela que o poeta, num outro passo do mesmo ensaio, considerava "a rainha das faculdades humanas". A fotografia seria útil, admitia Beaudelaire, como uma prótese da memória, mas estava fora de questão atribuir-lhe a função e o estatuto das "Belas-Artes”, porque, como também 
vaticinava: "se lhe for permitido usurpar o domínio do impalpável e do imaginário, de tudo aquilo que apenas tem valor porque o homem the acrescenta alma, então, desgraçados de nós!» (AA.VV. 2013: 103).

Sabemos bem que não foi apenas Baudelaire a escandalizar-se e a desdenhar daquela que começou por ser considerada apenas uma invenção mecânica, ou seja, do foro da reproductibilidade técnica da imagem. Muitos intelectuais e artistas em Oitocentos, e mesmo posteriormente, tenderam a avaliar de forma precipitada e preconceituosa a natureza e o alcance da transformação social, cultural e artística de invenções como o daguerreótipo ou, mais tarde, do cinematógrafo. Fizeram-no naturalmente condicionados por aquele que era o "estado da arte" à época, sabendo nós que o visionarismo nunca foi uma qualidade comum, nem aplicável genericamente.

Outra seria já a abordagem de Walter Benjamin ao referir-se "à loucura da fotografia”, como o momento em que "o espírito, ultrapassando a mecânica, converte os seus resultados exactos em parábolas da vida" (1992: 132). De acordo com esta ideia de fotografia, existe uma pequena luz do acaso, em virtude da qual a realidade incendeia a imagem, pelo que a fotografia, tal como a poesia, é uma arte de "Incêndio dos Aspectos" (Ramos Rosa). Em virtude desse acto incendiário, rompe-se com a referência objectiva e busca-se uma percepção originária do mundo, o que significa uma inflexão fundamental, uma vez que a fotografia deixa de estar subsumida à visibilidade anterior ao registo da câmara, passando a experimentar outras formas de revelar a realidade. Esse modo de conhecimento intuitivo-poético actualiza-se quando a fotografia perturba as normas estéticas ou as diferentes condições (históricas, sociais, políticas, culturais ou religiosas) que instruem o nosso olhar sobre o mundo, a partir de uma determinada ordem e fronteira entre o visível e o invisível.

Nesse sentido, a fotografia será tanto mais reparadora do nosso campo de visibilidade do mundo quanto mais for capaz de dar a ver a ambiguidade de todas as formas da realidade, ou seja, quanto mais revelar o momento em que a realidade vacila, quanto mais se transformar numa visão poética enquanto alteridade do ver: "otredad del ver”, na expressão de Llorenç Raich Muñoz (2018: 230). Escreve a propósito François Soulages, na sua Esthétique de la Photographie:

É porque a fotografia, na sua própria essência, fica esvaziada do sentido que a realidade podia ter, que o receptor, passado o momento da confusão, pode atribuir-lhe novos sentido ligados à sua subjectividade e ao seu imaginário: a fotografia de alguma coisa permite sempre imaginar outra coisa. A fotografia é a arte do imaginário por excelência, bem mais que o cinema, talvez porque seja muda, sem movimento, sem futuro, um simples pedaço de não-sentido que apela a um investimento imaginário por parte do receptor. (200I: 67; trad. minha) 
Embora seja fundamental esta disponibilidade lenta e projectiva por parte de quem olha, de modo a ver "com olhos de ver", tudo depende também do tipo de imagem fotográfica com que se depara. Se o fotógrafo investe numa representação tautológica ou convencional dos referentes para que aponta, isso impede naturalmente que os espectadores passem além dessa "crosta do mundo" (Tisseron 1996: 115) que, como tal, obstaculiza a passagem da luz que dará outras formas à imagem.

Existem vários modos de desrealizar uma imagem fotográfica, de a resgatar da submissão aos contornos indiciais, o que todavia não significa falseá-la, submetendo-a a outras prerrogativas. A estética de cada fotógrafo acaba por privilegiar alguns desses modos que passam, por isso, a revelar a sua assinatura fotográfica, ou seja, o seu modo mais próprio de ver e dar a ver a realidade. 0 fotógrafo checo Josef Sudëk, por exemplo, utilizava bastante o efeito desfocado que, ao invés de representar uma fotografia falhada, como acontece no âmbito do uso corrente da fotografia, confere expressão ao devir infinito das coisas. 0 desfocado impede que as fotografias congelem a ilusão de um objecto perdido para sempre, para que apontava a visão da fotografia em Roland Barthes, rebatida por Serge Tisseron, autor de Le Mystère de la Chambre Claire, quando escreve: "Ela [a fotografia] não evoca a destruição do mundo e a sua sobrevivência precária através da imagem; mas pelo contrário a sua incessante transformação. E esta não é melancólica, mas pelo contrário exaltante, porque permite-nos descobrir aqueles que amamos diferentes a cada instante" (Tisseron 1996: 83).

Para outro fotógrafo, o americano Minor White, para quem a função da câmara consistia em invocar o invisível do visível, fotografar significava aceder a um estado de reflectida contemplação, dado que invocar é tão diferente de evocar, como o desconhecido é diferente do lembrado. Aquele fotógrafo americano contribuiria também para o desenvolvimento da concepção de série fotográfica, a que deu o nome de sequence - um conjunto de fotografias sobre um determinado tema, cuja sucessão dá origem a uma “imagem mental”, uma espécie de "terceira imagem invisível” emergente do espaço entre duas fotografias.

Num e noutro caso, as fotografias não criam a ilusão da restituição do instante passado, e tão-pouco se deixam impregnar da nostalgia bloqueadora da repetição; pelo contrário, tornam manifesto que a sua força rememorativa reside essencialmente no facto de potenciarem no espectador uma relação aberta, não de confirmação, mas de interrogação, com a (in)visibilidade do mundo.

\section{Flash - Será a beleza salvífica?}

Retomo agora a ideia de "salvação", que evitei ao longo dos flashes anteriores, para a associar a uma célebre expressão retirada do romance $O$ Idiota de Dostoiévsky, segundo a qual o Príncipe Myschine, o Idiota, teria uma vez afirmado que a beleza 
salvaria o mundo. Em rigor, não é ele que profere tal afirmação - e esse pormenor de enunciativo está longe de ser irrelevante -; é-lhe atribuída por Ippolit, um jovem niilista, nos antípodas da mundividência de profunda confiança no ser humano de Myschine, cuja bondade é interpretada como imbecilidade ou ingenuidade (Dostoiévsky 200I: 396). E Ippolit vai mais longe, nesse que até certo ponto parece um confronto entre Ippolit-Pilatos e Príncipe Myschine-Cristo, ao afirmar que essa “ideia jocosa” ficava a dever-se ao facto de Myschine estar apaixonado. Aquilo que, na boca satírica de Ippolit, constituía um disparate, no projecto do romancista russo fazia parte da aliança entre um ideal de perfeição e uma profunda empatia pelo mundo, encarnada por Myschine.

Por conseguinte, a noção de beleza salvífica não representa apenas, nem fundamentalmente, um atributo estético, antes remete para aquela que é a tradição do ideal ateniense da kalokagathia, isto é, a íntima ligação entre "belo" e "bom”, tal como se encontra, por exemplo, nos diálogos de Platão, nomeadamente em Filebo, onde pela boca de Sócrates é declarado que a essência do Bem se refugiu na natureza do Belo. Na Bíblia será desenvolvida essa mesma aliança genesíaca, pela qual a beleza é a expressão visível do bem, tal como o bem é a condição metafísica da beleza, e ambos revelam a verdade da Criação.

Se bem que ao longo da História a Arte, domínio por excelência do belo, se tenha, em geral, secularizado, ao tornar-se autónoma do discurso religioso, o ideal de absoluto que perseguem, por exemplo, os poetas e outros artistas modernos, concentrado na procura da verdade na própria arte, é ainda sinal dessa fundamental irmandade, glosada por Emily Dickinson num dos seus poemas, intitulado justamente "Beauty and Truth".

Por outro lado, ao contrário de uma ideia de beleza intrínseca ao mundo, que caberia apenas descobrir, um autor como David Hume, já no século XVIII, lembrava que a beleza não é uma qualidade das coisas e que ela existe apenas na mente de quem as contempla, razão pela qual existem concepções distintas de beleza, que estão longe de significar um olhar apenas ou fundamentalmente individual. De resto, sabemos bem que a beleza ou os seus diferentes padrões têm sido socialmente instituídos como um modo de organização e de controlo, processo esse para que a fotografia tem também concorrido desde os seus inícios, enquanto registo selectivo e, muitas vezes, como exemplo justamente de beleza, entretanto cada vez mais padronizada e mercantilizada, ao ponto de fazer do espectador um mero consumidor de imagens-cliché, seja de paisagens, pessoas ou animais, segundo modelos e efeitos pré-formatados.

Sendo certo que nunca nenhuma forma de beleza salvou o mundo da guerra, da fome, da injustiça ou da morte, e ainda que - como sói acrescentar-se, com indisfarçável frustração ou cinismo - o culto da beleza da Arte e a prática das maiores atrocidades coexistam por vezes numa mesma pessoa ou numa mesma sociedade, 
convirá ter em conta que esse tipo de argumentos lida com a beleza como uma certa convenção estética, e não exactamente como uma relação de afecto entre sujeito e objecto, uma relação inquietante e perturbadora, ao ponto de o indivíduo sentir uma profunda sensação de verdade, de justeza, a emanar de uma determinada obra de arte, como uma energia de revelação e de transformação. Quer então isto dizer que a fotografia, tal como qualquer outra arte, só será salvífica se for "uma gramática e uma ética da visão" (Sontag 1983: 13) que concorre para a "pedagogia do ver" de que fala Byung-Chul Han (2015: 21), porquanto obriga a desacelerar, selecciona, amplia e transforma a nosso modo de percepcionar a realidade.

Enquanto há imagens fotográficas que se limitam a repetir formas estereotipadas ou convencionais de beleza, outras há que conseguem transmitir a sua experiência do mundo como uma revelação, ou seja, apontam sem necessariamente mostrar. Mas nenhuma fotografia, por mais interessante que seja, repara directamente o mundo, exige sempre a mediação do espectador, ou seja, a recepção por um corpo e mente dispostos a absorverem e deixarem-se transformar por essa forma fragmentária de alteridade.

Depois destes seis flashes, seis ângulos de abordagem da relação entre fotografia e "salvação do mundo", volto ao autor de $A$ Sociedade do Cansaço, quando associa a perda da capacidade contemplativa à histeria e ao nervosismo da sociedade moderna (Han 2015: 50), não exactamente para fazer uma defesa e ilustração da fotografia como forma de terapia, pelas reservas apontadas no início ao eventual reducionismo dessa forma de convívio com a arte, e porque existem modos de fazer e de ver fotografia que, afinal, concorrem para aquela histeria. Em contrapartida, gostaria de salientar a dimensão potencialmente libertadora e emancipatória da fotografia, em especial quando associada a uma auto-crítica descodificadora, como lembrava nos anos '80 o filósofo Vilém Flusser, ao alertar para o perigo da robotização do universo fotográfico e da sua extensão a toda a sociedade pós-industrial (Flusser 2000: 41). Daí a proposta do autor de Towards a Philosophy of Photography para que a crítica da fotografia funcionasse como modelo de disrupção criativa do apparatus e, em última análise, de uma filosofia empenhada na existência presente e futura dos seres humanos (ibidem: 75).

Talvez imaginar um mundo sem imagens constitua a forma mais eficaz de mostrar a importância da fotografia, que é o que faz Joanna Zylinska, autora de A Fotografia depois do Humano (2019), quando apela ao romance de ficção científica Time and Light, de William Bornefeld. Mas não é com essa distopia que quero terminar, ou talvez suspender esta reflexão. Pelo contrário, opto por apresentar uma sequência de 24 imagens fotográficas da minha autoria, em deliberada réplica aos clássicos 24 qps no cinema, que aqui desvinculo da repetição e da ilusão mecânica do movimento a que está obrigada a cadência cinematográfica.

Aviso, no entanto, que não deve procurar-se nesta espécie de álbum vertical qualquer ilustração do que antes ficou escrito, nem tão pouco provas de qualquer 
virtuosismo técnico. Tome-se esta sequência como um prolongamento, como outra forma de construção e de partilha de um discurso pensante em torno da relação que me propus explorar entre fotografia e salvação do mundo. Exactamente porque são fotografias sem qualquer texto que as identifique ou situe, a sua sequência deve ser vista como um álbum aberto ao discorrer de cada um/a, para que continue a pensar com elas, contra elas e para além delas. Isto porque se existe algo de salvífico na relação com a fotografia é justamente essa possibilidade de absorver a compenetração do olhar da Medusa sem a ele sucumbir.

\section{Notas}

* Ana Paula Coutinho é Professora de Literatura Comparada e de Estudos Franceses na Faculdade de Letras do Porto. Investigadora e actual Coordenadora Científica do Instituto de Literatura Comparada Margarida Losa, tem publicados vários estudos sobre a literatura dos séculos XX-XXI, a partir da análise de problemáticas transversais e interdiscursivas. Nos últimos anos, tem-se dedicado, em especial, ao estudo das representações literárias/artísticas das migrações e do exílio e respectivas implicações estéticas e éticas, assim como à investigação em rede e à edição colaborativa. Amante de longa data da Fotografia, usa a câmara, sempre que pode, para pensar no que vê e para rever o que pensa.

' Para o autor de Für eine Philosophie der Fotografie (1983), o termo designa um aparelho sofisticado como a câmara fotográfica ou “caixa-preta”, que não é apenas um objecto, um utensílio ou ferramenta, mas uma forma de agenciamento cultural sujeito a uma complexa programação.

2 Até Baudelaire, completamente insuspeito de apreciar a fotografia, por ver nela uma restrição das possibilidades do real, reconhecia-lhe essa função de serviço às ciências e às artes, como pode ler-se em “O público moderno e a fotografia”.

${ }^{3}$ Assim o provaram, por exemplo, Larry Sultan e Mike Mandel, autores do projecto artístico Evidence (1977), que retiraram de arquivos institucionais documentos fotográficos de diversos acontecimentos; expurgaram-nos de qualquer informação contextual e, por fim, montaram uma sequência de imagens, onde aquilo que havia sido documental passou a funcionar como artefacto. .

${ }^{4}$ Vd. o meu ensaio “ «Escrever com a luz» as migrações humanas: Sebastião Salgado entre estética e ética” (Coutinho 2016). 


\section{Bibliografia}

AA.VV., (2013), Ensaios sobre Fotografia de Nièpce a Krauss, org. Alan Trachtenberg, Lisboa: Orfeu Negro.

Barthes, Roland (1980), La Chambre Claire, Paris, Gallimard. [ed. ut.: A Câmara Clara, trad. Manuela Torres, Lisboa, Edições 70, 2014].

Baudrillard, Jean (1970), La Société de Consommation, Paris, Éditions Denoël.

Benjamin, Walter (1992), Sobre Arte, Técnica, Linguagem e Política, Lisboa, Relógio d'Água.

Bourdieu, Pierre (1965), Un Art Moyen. Essai sur les usages sociaux de la photographie, Paris, Minuit.

-- (1992), Les Règles de l'Art. Genèse et structure du champ littéraire, Paris, Minuit.

Boym, Svetlana (200I), The Future of Nostalgia, Nova Iorque, Basic Books.

Coutinho, Ana Paula (2016), “Escrever com a luz» as migrações humanas: Sebastião

Salgado entre estética e ética”, Cadernos de Literatura Comparada, 34, p. 31-55.

Debord, Guy (1967), La Societé du Spectacle, Paris, Buchet / Chastel.

Didi-Huberman, Georges (2002), Quand les Images Prennent Position. L'œil de l'histoire, I, Paris, Minuit.

Dostoiévski, Fiódor (200I), O Idiota, trad. Nina Guerra e Filipe Guerra, Lisboa, Editorial Presença.

Feldhues, Marina/ Júnior, José Afonso (2020), “A história do Outro em Gênesis de

Sebastião Salgado: uma leitura anticolonial do capítulo Tribos de Irian Jaya, Indonesia”, Interin, v. 25, n. 2, jul./dez. 2020, p. III-I29.

Fœssel, Michaël (2012), Après la Fin du Monde. Critique de la raison apocalyptique, Paris, Seuil.

Flusser, Vilém (1983), Für eine Philosophie der Fotografie [ed.ut. Towards a Philosophy of Photography, trad. Anthony Mathews, Londres, Reaktion Books, 2000].

Han, Byung-Chul (2015), The Burnout Society, Standford University Press.

Muñoz, Llorenç Raich (2018), Fotografía como Poesia, Lisboa, Casimiro Libros.

Rancière, Jacques (2000), Le Partage du Sensible, Paris, La Fabriques des Idées.

Sontag, Susan (2012), Ensaios sobre Fotografia, trad. José Afonso Furtado, Lisboa, Quetzal.

-- (2015), Olhando o Sofrimento dos Outros, trad. José Lima, Lisboa, Quetzal. Soulages, François (200I), Esthétique de la Photographie, Paris, Nathan.

Tisseron, Serge (1996), Le Mystère de la Chambre Claire, Paris, Flammarion.

Zylinska, Joanna (2019), A Fotografia depois do Humano [2016, trad. Gabriela Baptista, Rio de Janeiro: Zazie. 


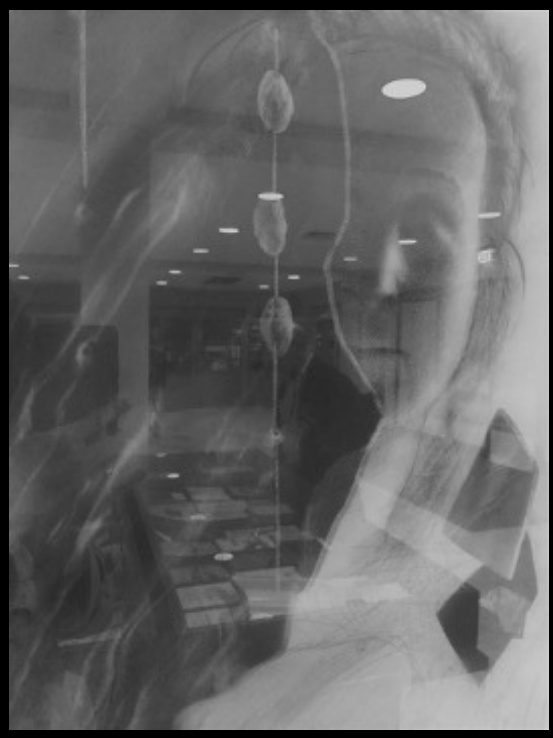



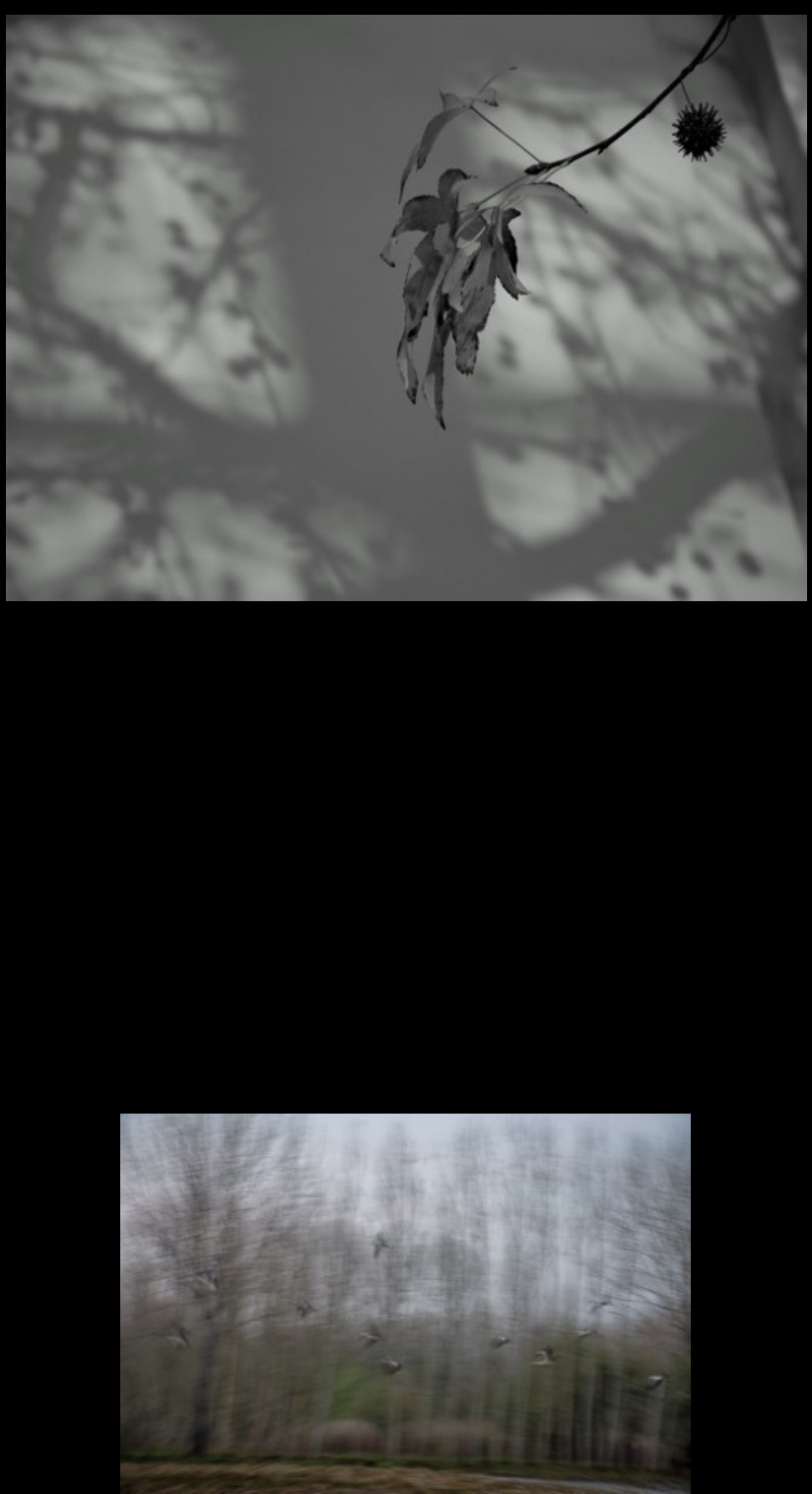

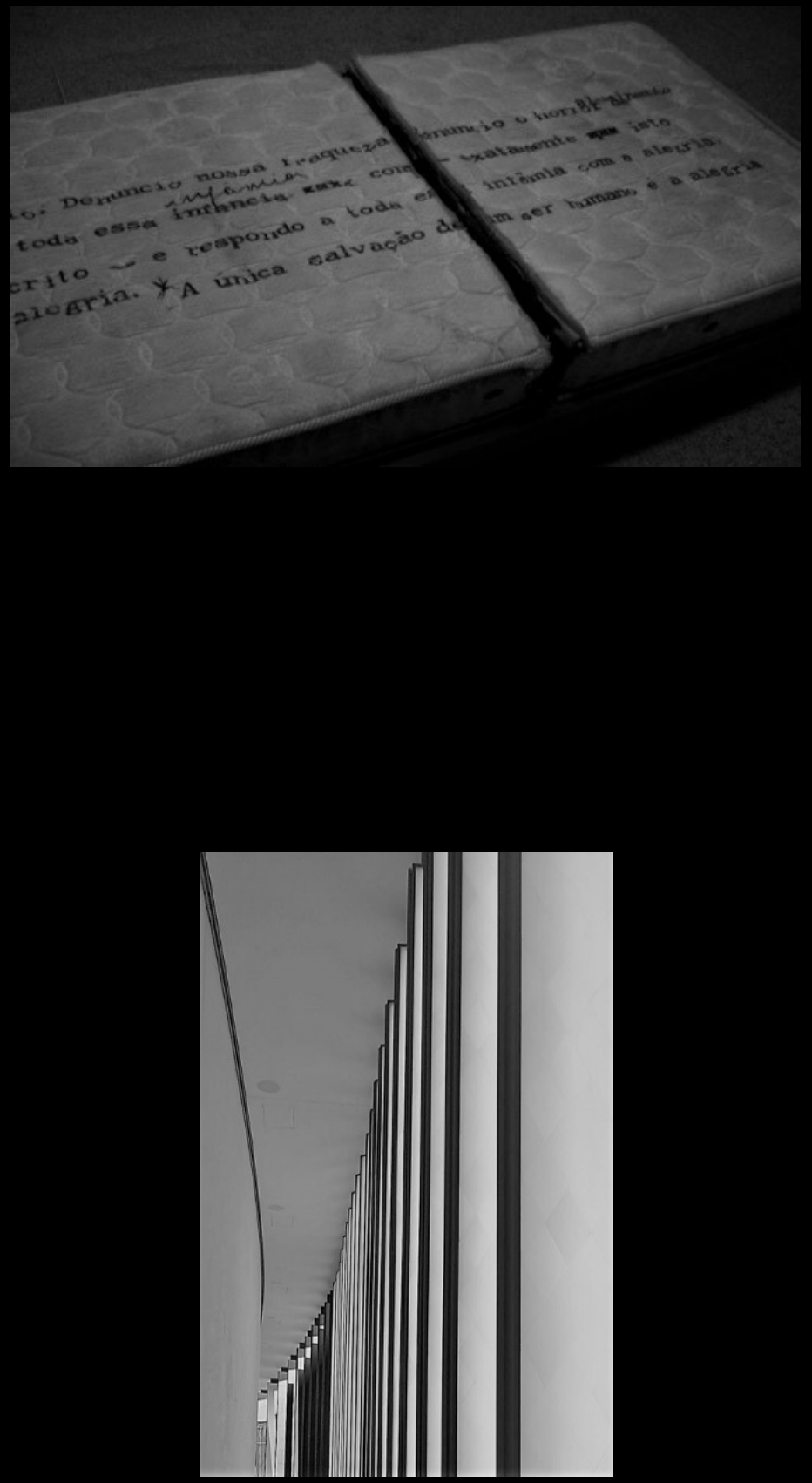

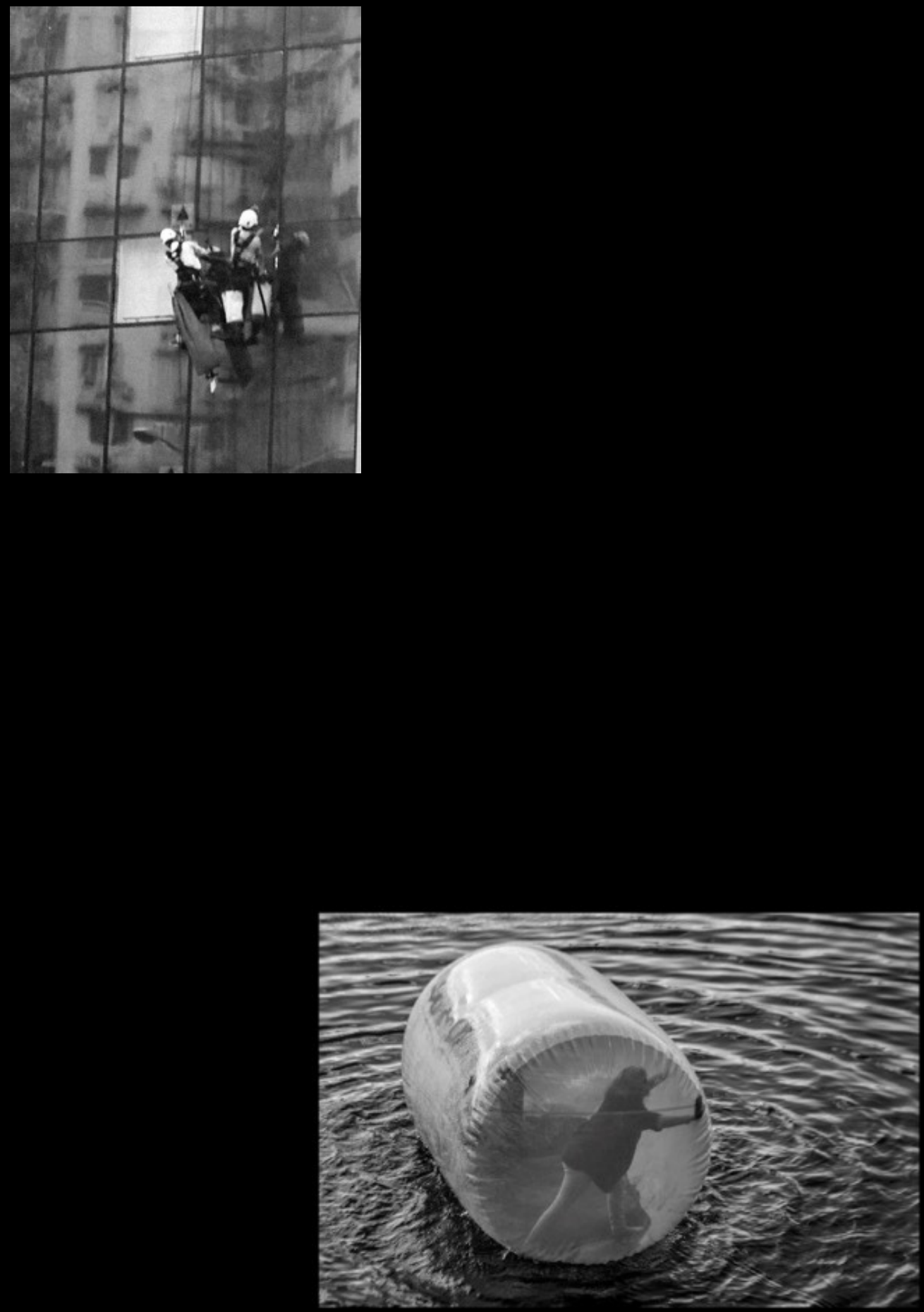

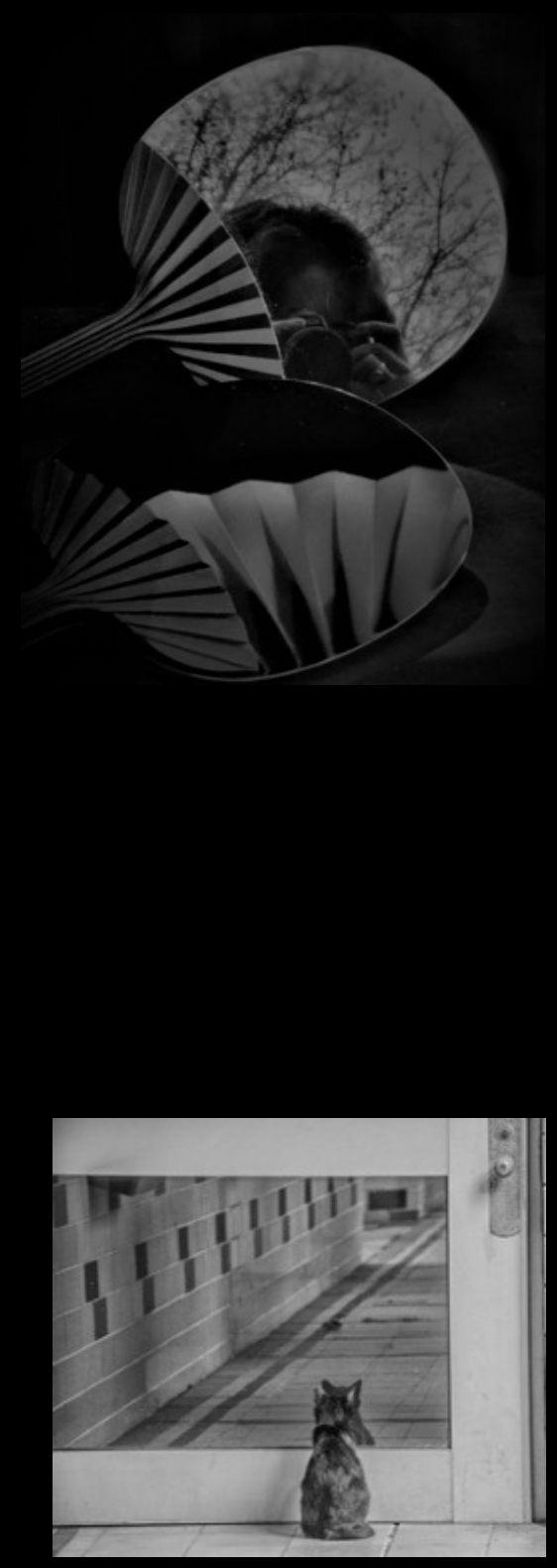

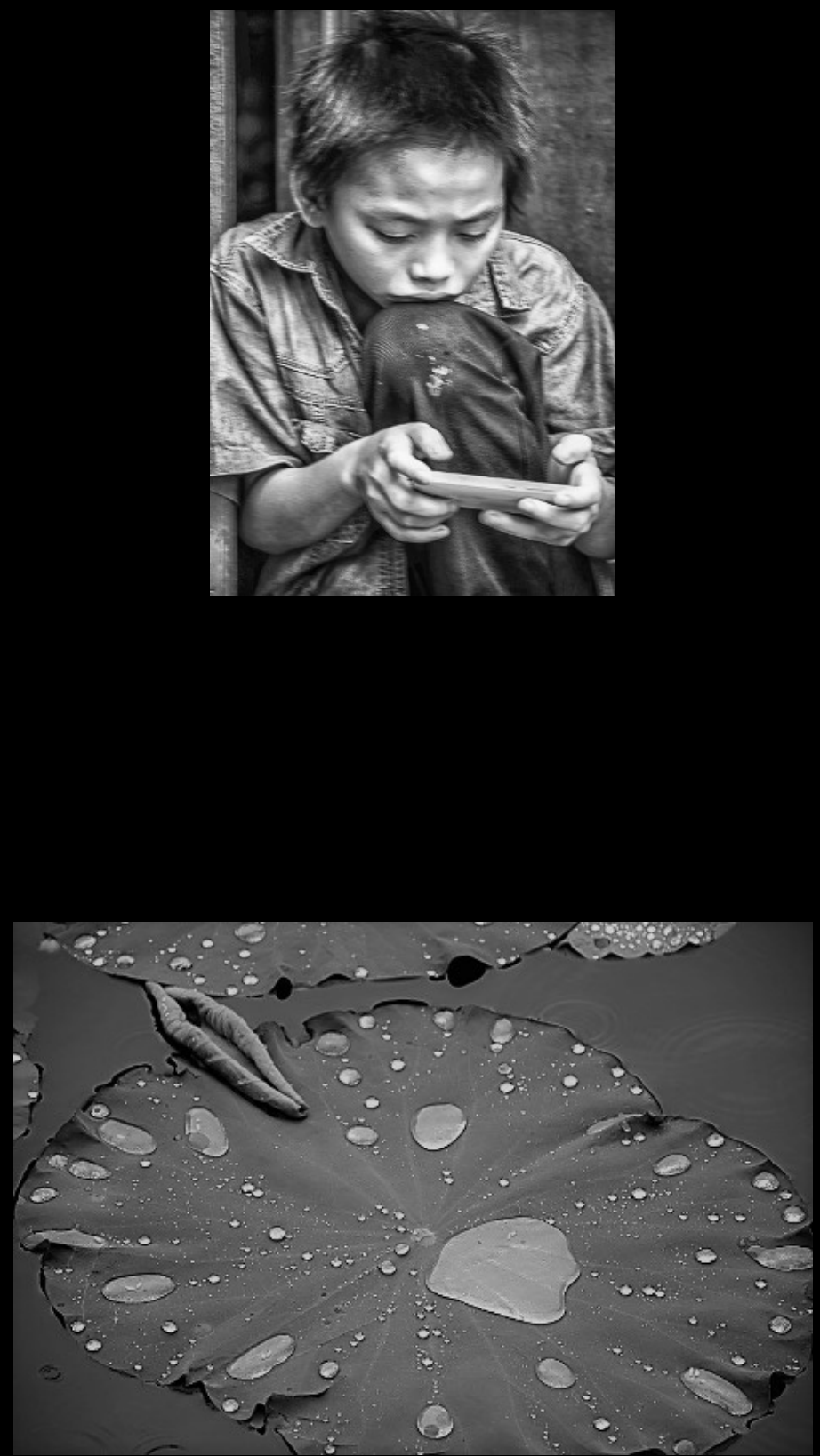

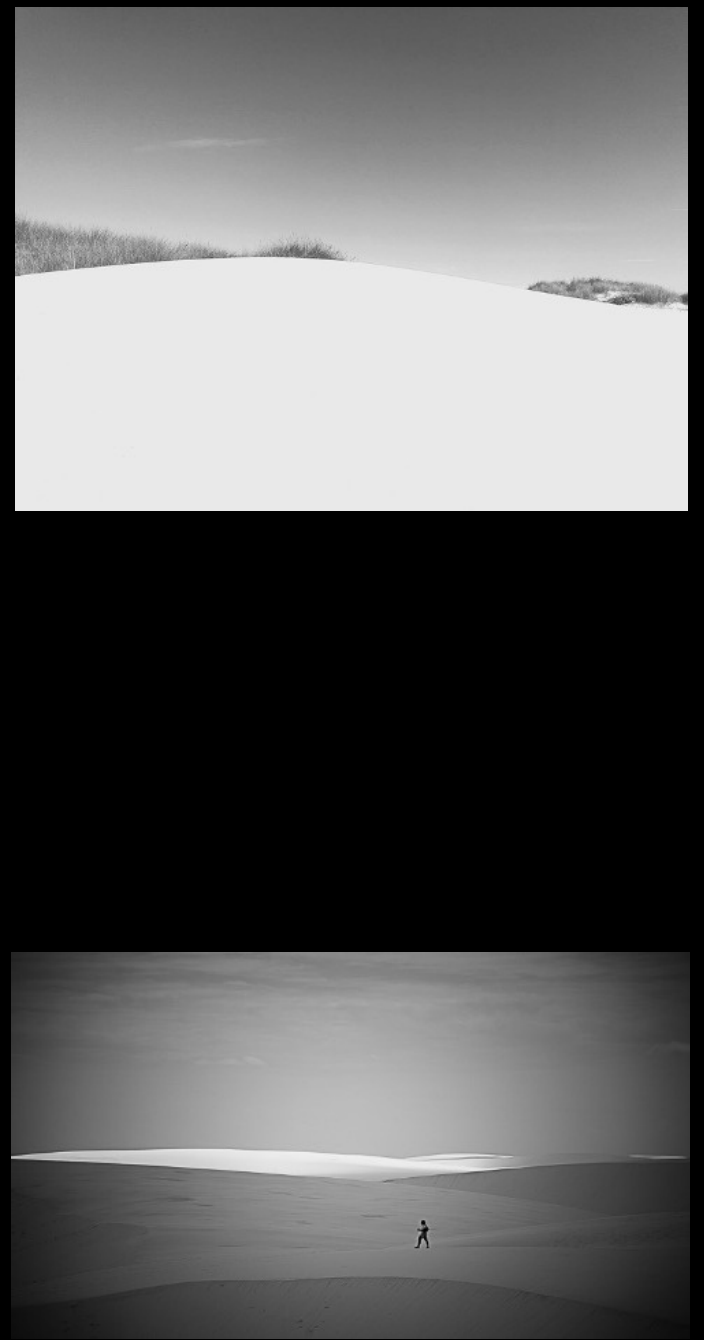

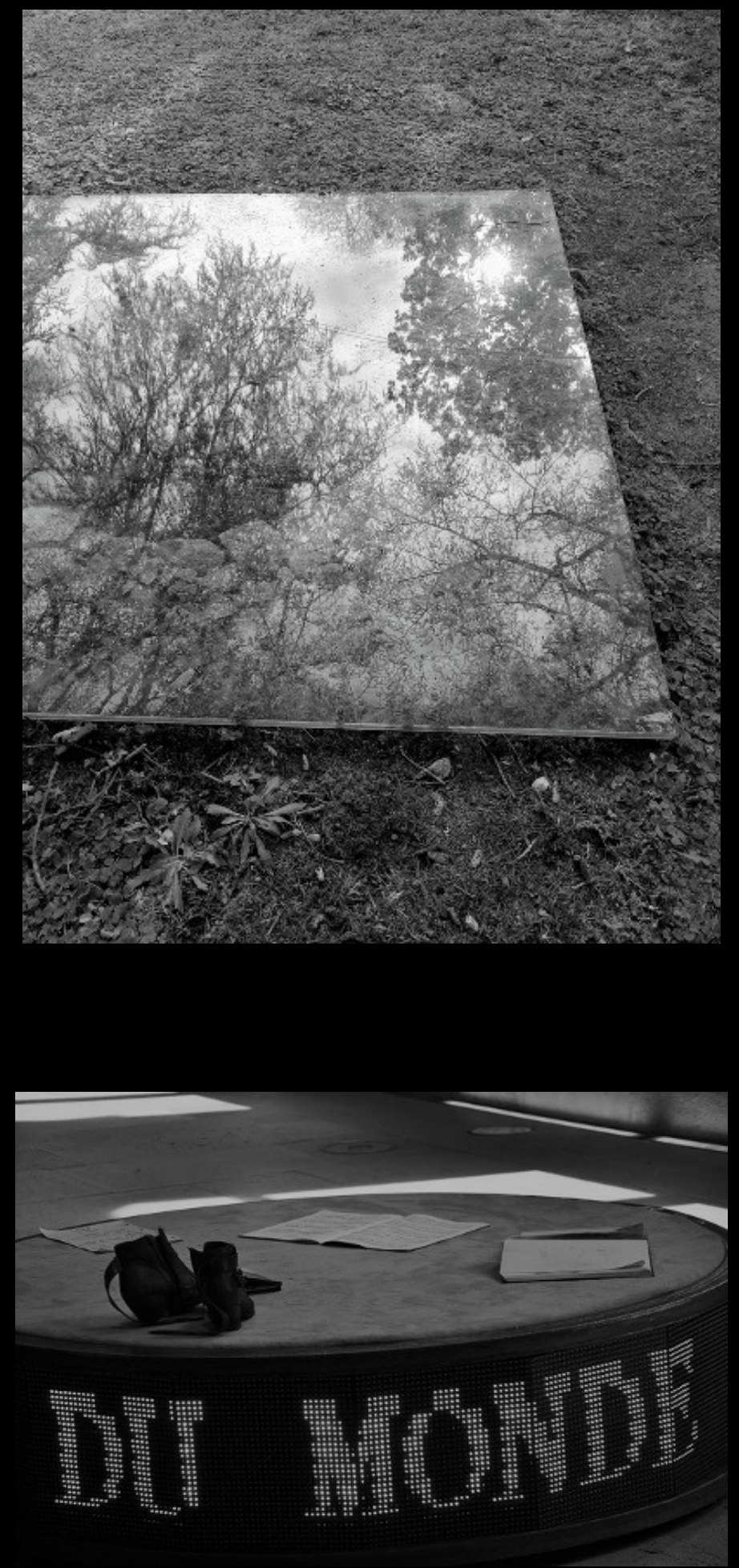

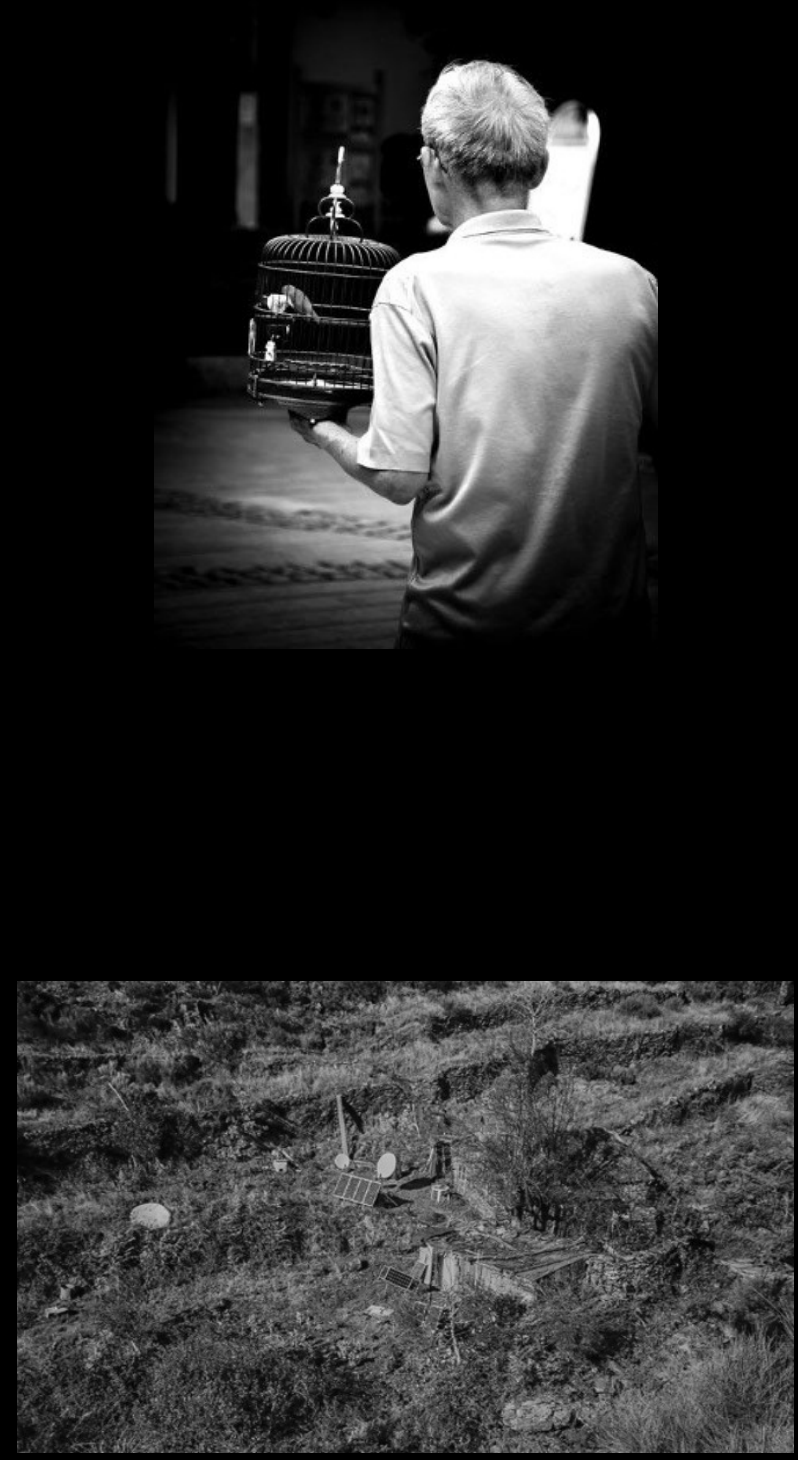

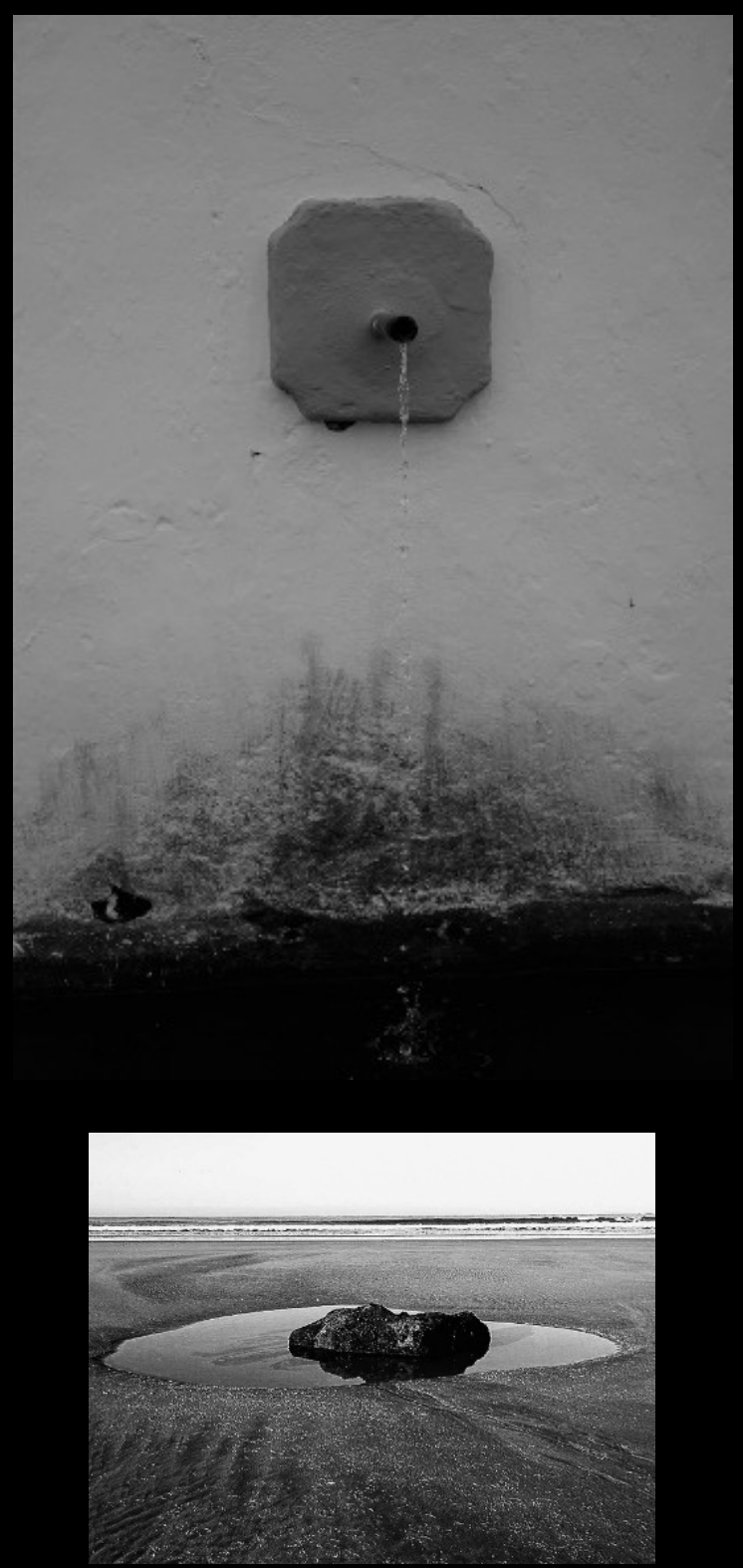

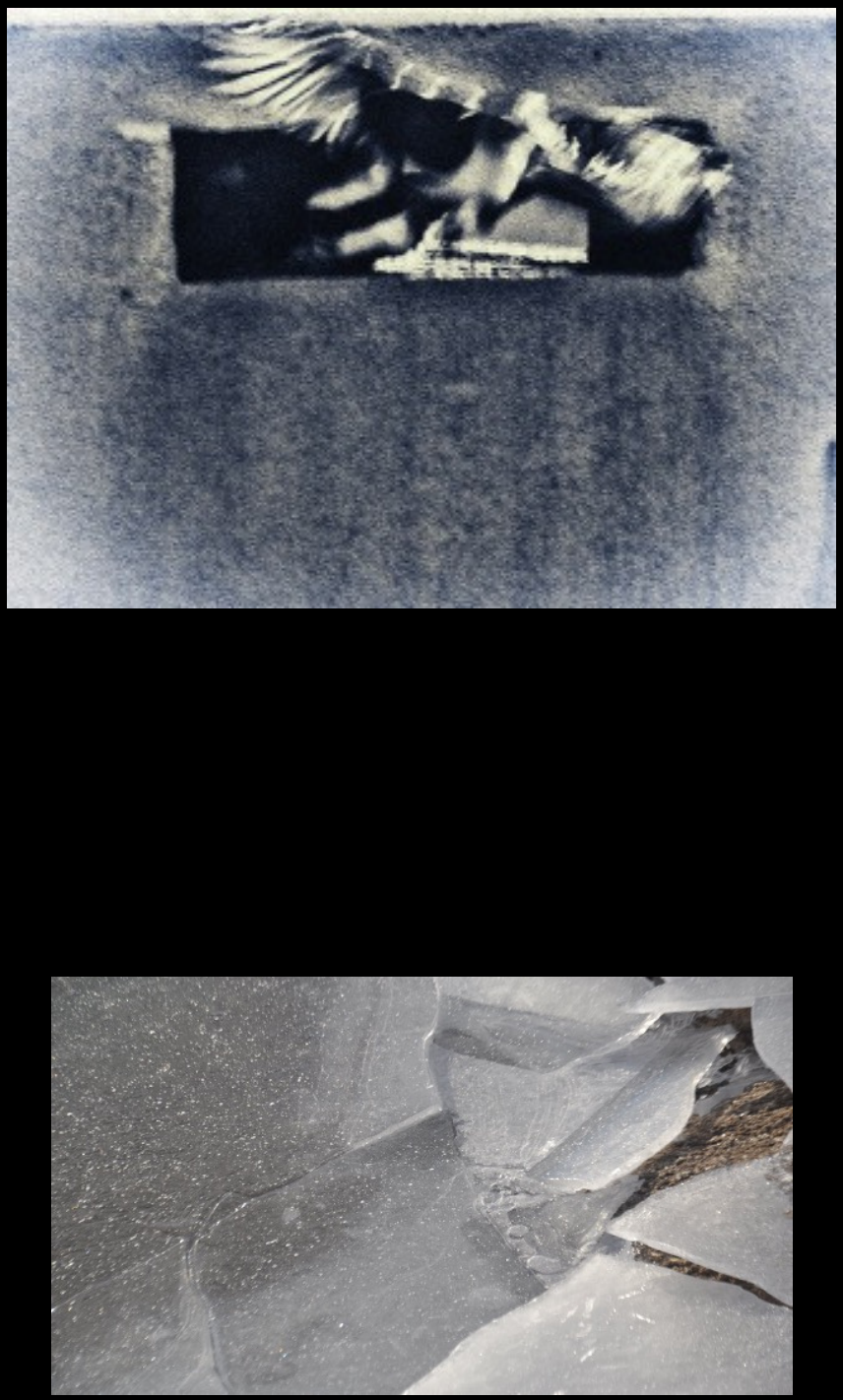
